\title{
К ВОПРОСУ О СООТНОШЕНИИ ОБЫЧНОЙ И КОНВЕНЦИОННОЙ НОРМ ОТНОСИТЕЛЬНО ВЛИЯНИЯ ИЗМЕНИВШИХСЯ ОБСТОЯТЕЛЬСТВ НА СИЛУ МЕЖДУНАРОДНОГО ДОГОВОРА
}

\author{
M.A. Короле в *
}

Вот уже несколько столетий государства, стремящиеся избавиться от того или иного связывающего их договора, ссылаются подчас на изменение обстановки, имевшее место со времени его заключения, иными словами, используют возмохностъ, предоставляемую, как утверждает доктрина международного права, принципом, нзвестным как клаузула rebus sic stantibus, причем в большинстве случаев не упоминая даже ее названия.

Все эти годы вохруг данного явления ведутся весыма оживленные споры как на теоретическом, так и на практическом уровне. Суть возникающих разногласий сводится к следующим основным вопросам: получает ли в принципе государство, rebus mutatis, право заявлять о прекрашении договора; если да - то каковы природа и степень достаточности оправдывающих подобные действия изменений; наконец, каковы последствия такого влияния, прежде всего процедурные?

Слегка опережая события, отметим весьма любопытную и познавательную закономерность: при всем многообразии подходов, обусловленном сильным влиянием на соответствующую область международного права национальных правовых дохтрин, наиболее ошутимой границей между различными точками зрения стало восприятие данных вопросов юристами и правительствами стран континентальной и общей систем права.

Однако в 1969 году Венской конференцией по праву междунарапных договоров была принята одноименная конвенция, в которо содержится статья 62, посвященная коренному нзменению бстоятельств. Казалось бы, что, явившись итогом многолетних обсухдений в Комиссии международного права ООН (КМП) и став компромиссом не только между личными мнениями правоведов разных стран, но и официальными подходами последних, статья 62 должна была бы свести на нет все прежние кривотолки и споры, предоставив государствам и судам единообразное и всех устраиваюшее понимание сушества соотношения между изменением обстоятельств и сохранением договора в силе. Тем более что созданная конвенционная норма, по утверждению многих, якбы стала бук-

* Соискатель кафедры международного права МГИМО(У) МИД РФ. 
вальной кодификацией обычной' и сама имела достаточную универсальность, чтобы рассматриваться в качестве таковой до вступления конвенции в силу.

На деле же все обстояло не столь гладко. Обратимся к международной практике последующих лет.

Первым и по сей день единственным случаем рассмотрения подобных вопросов в Международном Суде ООН (далее - Суд) по прннятии Венской конвенции 1969 года стал спор межцу Великобританией и Исландией - Дело о юрисдикции по спорам о рыболовстве (Fishers Jurisdiction Case). В 1972 году Исландия решила расширить свою рыболовную зону с 12 до 50 морских миль. Великобритания обратилась 14 августа того же года в Суд, сославшись (в соответствии с $\$ 1$ статьн 36 Статута) на соглашение от 11 марта 1961 г., заключенное этими странами, в котором признавалось требование Исландии о 12-мильной ширине рыболовной зоны наряду с передачей любой из сторон всякого спора, относяшегося $\mathrm{K}$ расширению зоны за означенные пределы, на рассмотрение Суда ${ }^{2}$. Правомочность Суда рассматривать данное дело Исландия не признавала. 2 февраля 1973 г. большинством голосов Суд вынес решение о возможности установления собственной юрисдикции и рассмотрения спора по существу. Отказавшись уведомить Суд о своей официальной точке зрения по данному вопросу, Исландия, тем не менее, заявила в меморандуме, направленном британскому правительству, что «считает соглашение 1961 года более неприменимым и прекратившим, таким образом, свое действие» ${ }^{3}$. В качестве обоснования своего подхода Исландией были упомянуты происшедшие изменения как в праве - 12-мильная ширина территориального моря стала общепризнанной со времени заключения соглашения 1961 года, и поэтому последнее являлось якобы необязательным, так и в самой природе - рыбные запасы за истекшие годы истощились, а техника их добычи значительно улучшилась. Расценив ссылки Исландии на rebus mutatis как применение статьи 62 Венской конвенции 1969 года, Суд признал, что «изменения в области права при определенных условиях могут послужить основанием для ссылки на них как на коренное изменениц обстоятельств, влияющее на действительность договора», однако не счел, что «данное правило имеет отношение к рассматриваемому им спору, поскольку цель соглашения 1961 года состояла не только в признании требований Исландии о 12-мильной ширнне рыболовной зоны, но также и в определении средств разрешения возможных разногласий, а в этом отношении никаких изменений в праве не произошло». Упомянув о том, что «одно из основных требований этой статьи (62-й) состоит в том, что изменение обстоятельсля должно быть коренным», Суд, что самое лю- 
бопытное, отметил: «Упоминание Исландией о своих «жизненных интересах»... должно быть рассматриваемо в связи с ее утверждениями об изменении обстоятельств. Тогда можно будет выяснить, почему Исландия полагает имевшие место изменения в рыболовстве коренными по сравнению с тем, что существовало ранее. Именно такое рассмотрение будет соответствовать установившейся традиции считать коренными только такие изменения в обстоятельствах, которые несут угрозу существованию или жизненно важным интересам одной из сторон». Ссылку на изменение техники рыболовства Суд признал несостоятельной, поскольку таковое «не может считаться коренным изменением, оказывающим влияние на действительность соглашения о признании обязательной юрисдикции Международного Суда». Развивая данную мысль, Суд, что не менее вахно, подчеркнул: «...Для того, чтобы изменение обстоятельств могло стать законным основанием прекращения договора, необходимо также, чтобы оно коренным образом изменяло сферу действия обязательств, все еще подлежащих выполнению. Подобное изменение должно столь увеличить бремя подлежащих выполнению обязательств, что таковые в итоге превращаются в нечто существенным образом отличаюшееся от ранее предусматривавшегося договором». И указал: «В отношении рассматриваемых ныне договорных обязательств данное условие никак не соблюдено: изменение обстоятельств, приводимое Исландией, не изменило коренным образом сферы действия юрисдикционных обязательств, возникших вследствие обмена нотами в 1961 году... Сфера действия означенных обязательств не только не претерпела коренных изменений, но, напротив, осталась совершенно той же, какой она была в 1961 году»".

Из этого дела можно извлечь весьма интересные для нас выводы: во-первых, хотя и признав, как того требует текст статьи 62, что изменение, достаточное для прекрашения договора, должно носить коренной характер, само понятие «коренной» Суд; причем убежденный в традиционности своего подхода, истолковал как несущее угрозу жизненно важным интересам сторон; во-вторы.х, затрагивание переменами сферы действия договорных обязательств разъяснялось им как увеличение бремени обязательств по сравнению с тем, которое изначально предусматривалось по договору5.

Не менее любопытен и следующий случай. В мае 1990 года парламент Финляндии направил письменный запрос правительству, в котором со ссылкой на «изменение обстановки на континенте» предлагал приступить $к$ действиям по отмене устаревших статей части III Парижского мирного договора 1947 года'. 17 сентября 1990 г. посол Финляндии в СССР передал в МИД СССР неофициальный документ, содержавший проект постановления 
финского правительства о прекращении действия части III договора 1947 года в отношении своей страны', сообшив также, что подобным же предварительным образом была уведомлена и Великобритания как другой жосновной участник договора». Ознакомившись с намерениями Финляндии, МНД СССР довел до ее сведения, что жсоветская сторона в целом положительно реагирует на бращение финляндской стороны и не будет возражать против отмены части III Мирного договора 1947 года или тех его статей, которые устарели и накладывают ограничения на сотрудничество с Германией», но отметил, что, «поскольку речь идет о многостороннем договоре, финляндской стороне было бы целесообразно до принятия своего решения заручиться согласием и других участников договора, чтобы действия Финляндии не выглядели как односторонний шагу. Однако в тот же день было принято решение правительства Финляндин о положениях Мирного договора, касающихся Германии и ограничивающих суверенитет Фннляндии, в котором говорилось, что «после объединения Германии и восстановления ее суверенитета правительство Финляндии считает, что положения части III Парихского мирного договора, касающиеся Германии, утратили свое значение», и подчеркивалось, что «другие полохения части III Мирного договора, ограничивающие суверенитет Финляндии, не соответствуют статусу Финляндии как члена ООН и как государства - участника СБСЕ. В связи с этим правнтельство констатирует, что и эти положения утратили свое значение» ${ }^{8}$ В ходе последовавших за отменой советско-финских консультаций МИД СССР ограничился выражением сдержанного недовольства поспешностью принятия означенного решения, а такхе высказал сожаление по поводу невнимания противоположной стороны $\mathbf{k}$ его пожеланию предварительно обсудить вопрос с остальными заинтересованными странами.

Из этого случая также можно сделать соответствуюшие выводы: во-первых, правомерность фактической ссылки Финляндии на теbus mutatis (балее того, без упоминания ст. 62) никем не оспаривалась; во-вторых, в качестве обоснования притязания выдвигалась утрата частью III своего значения и ограничение ее положениямн государственного суверенитета этой северной страны; в-третъих, отказ от договорных обязательств носил безусловно односторонний характер.

Нетрудно заметить, что основные выводы по этим двум прецедентам мало соотносятся с положениями и самим духом статьи 62, в принципе не допускающей применения ссылки на изменившиеся бстоятельства, а также накладывающей ограниңения на природу таковых (существенное основание заключения договора, что в рассмотренных случаях весьма сомнительно) и на характер перемен 
(коренным образом изменяют сферу действия обязательств, т.е. затрагивают договор непосредственно, оказывая воздействие, последствия которого граничат с физической невозможностью исполнения, а в приведенных примерах из практики расторгаемые договоры были еще вполне жизнеспособны). Кроме того, Венская конвенция 1969 года в принципе запрещает безусловное одностороннее прекращение договора, устанавливая обязательный срох для выяснения мнения других его участников, а при отрицательном отношении последних - и обязательную примирительную процедуру (ст. 64, 65).

Разумеется, Венская конвенция 1969 года и не должна была в обязательном порядке применяться в обоих этих случаях, ибо упомянутые договоры были заключены до того, как она вступила в силу в отношении Великобритании или Финляндин 9 . С другой стороны, статья 62 теоретически вполне могла бы быть задействована как обычная норма. Отчего же тогда при возникновении практической потребности избавить себя от договорных положений, ставших обременительными и не отвечающими современной обстановке, эти одобренные мировым юридическим сообществом формулировки остались не у дел, а в ход пошли хорошо известные нам по многовековой практике отказа от обязательств со ссылкой на rebus mutatis оправдания прекрашений, отражаюшие скорее стремление государства избежать неблагоприятных для себя последствий перемен обстановки, нежели озабоченность каким-то воздействием данных изменений на сам договор в той мере, в какой это могло бы действительно воспрепятствовать его предполагавшемуся осушествлению, беспокойство за его существование как самостоятельной ценности?

Быть может, члены КМП и участники Венской конференции, находясь под влиянием определенных доктринальных толкований клаузулы и найдя в конце концов некую приемлемую для всех усредненную формулировку, недостаточно учли действительную устоявшуюся практику государств по подобным делам, углубились в теорию и явили миру норму во многом искусственную, не отвечающую потребностям текушего применения, в отличие от обычной, естественным образом вырастающей из повседневной международной практики, прекрасно ей соответствующей и оттого свободно задействуемой заинтересованными государствами? Быть может, плоды их творчества, попав в обстановку государственного соперничества, уступили место испытанной временем обычной норме права относительно rebus sic stantibus? Если так, то становится понятным и толкование, данное по статье 62 Судом, столкнувшимся с чисто практическим случаем ссылки на изменившиеся обстоятельства, и приведенные выше доводы Финляндии. 
Чтобы ответить на поставленные вопросы, прежде всего надлежит выяснить, сушествует ли в международном праве упомянутая обычная норма, и в случае положительного ответа - установить истинное соотношение между ней и конвенционной нормой о коренном изменении обстоятельств, обратив внимание прежде всего на то, в чем их различие.

Рассмотрим практику межгосударственных отношений, которая, как известно, является единственным конструктивным элементом международного обычая, причем прежде всего уделяя внимание не столько заявлениям государств по данному вопросу, в отсутствие практики теряющим свое прецедентное значение, сколько фактическому поведению сторон ${ }^{10}$.

Известно весьма значительное число случаев, когда rebus mutatis ıосударство заявляло об отказе от договора. Чаще всего ссылки на изменившиеся обстоятельства приводили к действительному одностороннему прекрашению обязательств, и оно не получало широкого международного обсуждения, а если обратное и случалось, то значительного влияния на судьбу договора не оказывало, и поступавшие возрахения тех или иных затрагиваемых стран в расчет не принимались.

Так было, в частности, при:

- прекрашении САСШ в 1798 году союзного договора с Францией 1793 года со ссылкой на происшедшую там революцию"

- отказе Наполеона III от обязанности обеспечивать французское военное присутствие в Риме и поддерживать светские власти в папских областях Италии вследствие их занятия Виктором Эммануилом и гарибальдийской революции ${ }^{12}$;

- отказе России в 1871 году от установленной Парижским трактатом 1856 года нейтрализации Черного моря, когда участники Лондонской конференции, приняв ${ }^{13}$ декларацию, запрешавшую одностороннее расторжение договора ${ }^{14}$, все же согласились с русскими доводами, построенными на признании общего изменения политической обстановки в Европе ${ }^{15}$;

- отмене Россией в 1886 году без каких-либо принципиальных возражений иных держав ${ }^{16}$ порто-франко в Батуме по причине упразднения беспошлинного провоза иностранных товаров через Кавказ, ввиду чего порто-франко теряло смысл и становилось обременительным для местного населения ${ }^{17}$;

- аннексии. Австро-Венгрией в 1908 году Боснии и Герцеговины; сопровождавшейся прекрашением действия Константинопольской конвенции 1879 года, В оправдание чего выдвигалось укрепление мощи Турции, а также достижение этими балканскими странами уровня материальной культуры, достаточного для предоставления автономного конституционного рехима внутри империи, 
причем, судя по характеру заявления о присоединении, никто не собирался выносить данный вопрос на международное обсуждение, а последовавшие возражения ряда стран постепенно утихли в ходе частой дипломатической переписки ${ }^{18}$;

- провозглашении в 1908 году независимости Болгарии, молчаливо признанном всеми европейскими державами (до этого, согласно статье 25 Берлинского трактата 1878 г., Болгария формально считалась вассалом Турции ${ }^{19}$, что являлось, по мнению болгар, препятствием на пути поступательного развития их страны, ее вхождения в семью европейских народов, для чего за истекшие со времени установления зависимости годы были якобы созданы все необходимые условия ${ }^{20}$ );

- одностороннем прекращении Сербией в 1913 году Договора о дружбе и союзе с Болгарией 1912 года, устанавливавшего раздел приобретенных в ходе совместных военных действий территорий ${ }^{21}$, вследствие последующего значительного ущемления сербских интересов (чрезмерные и выходящие за установленные договором пределы территориальные приобретения Болгарии, ее вероломство во Фракии ${ }^{22}$, расширение круга сторон договора до четырех с соответствующим уменьшением отходяших участникам территориальных долей ${ }^{23}$ );

- прекрашении Германией в 1914 году действия в отношении себя договоров 1838 года ${ }^{24}$;

- расторжении Норвегией в 1922 году, со ссылкой на изменение политической обстановки в Европе и мире, договора 1907 года с Германией, Францией, Великобританией и Россией ${ }^{25}$;

— отказе Франции в 1932 году от соглашения с США, касавшегося долгов, предпосылкой которого было поступление репарационных платежей от Германии (в Национальном собрании было заявлено, что «в силу признанного принципа международного публичного права договоры и соглашения должны исполняться sic rebus stantibus» ${ }^{26}$, и принято постановление об утрате соглашением исполнительной силы вследствие полного изменения решаюших обстоятельств, под которыми в данном случае подразумевался режим германских выплат);

- временном прекращении в 1941 году действия в отношении США Конвенции о грузовой марке 1930 года ввиду перехода в состояние войны большинства из участвовавших в ней государств и наступления неблагоприятных последствий для американского торгового флота, проистекавших из установленных упомянутым соглашением пределов загрузки морских судов ${ }^{27}$;

- досрочном прекращении Советским Союзом в 1945 году Пакта о нейтралитете с Японией 1941 года, подлежавшего денонсацин $^{28}$; 
- расторжении Египтом в 1951 году, после безуспешной попытки решения данного вопроса в рамках Совета Безопасности $\mathrm{OOH}^{29}$, договора с Великобританией 1936 года $^{30}$, который, по утверждению египетской стороны, был заключен в иной мехдународной обстановке и ко времени отказа исчерпал свое назначение;

- отмене СССР в 1960 году положений Совместной декларации с Японией относительно передачи последней островов Хабомаи и Шикотан по заключении мирного договора между обеими странами ${ }^{31}$;

- выходе Франции из военных структур НАТО в 1966 году, сопровождавшемся расторжением ряда двусторонних соглашений, в ббоснование чего выдвигалось утверждение о коренном изменении с 1949 года обстановки в мире ${ }^{32}$;

- уже упоминавшейся отмене Финляндией положений части III Парихского договора 1947 года.

Несмотря на многочисленные оспбенности каждого из перечисленных прецедентов, можно, без сомнения, выделить некоторые положения, составлявшие устойчивое правило поведения, коғорое «достаточно четко в целом рассматривалось ${ }^{33}$ как необходимый стандарт поведения ${ }^{34}$. Отметим также, что непосредственно заинтересованные стороны никогда не возражали против самой возможности ссьлки на rebus mutatis, а лишь изредка оспаривали ее применимость к данному конкретному случаю. Так было, в частности, при отказе России от нейтрализации Черного моря, когда Англия не признавала одностороннего характера отказа; при отмене Турцией рехима капитуляций, когда протестовало большинство из непосредственно затрагивавшихся стран ${ }^{35}$; при отказе Финляндии от части III Договора 1947 года, когда вначале СССР высказался против одностороннего отказа и признал его впоследствии.

В большинстве же случаев данный вопрос $\infty$ ходили стороной, и в итоге возможность применения в соответствующем деле ссыли на rebus mutatis молчаливо признавалась. Это также имело место, помимо уже приведенных случаев, и с исключением из них особо упомянутых трех, и при пересмотре Германией некоторых статей Готардского договора ${ }^{36}$, равно как и в ходе расторжения Китаем договора 1865 года с Бельгией ${ }^{37}$.

Следует отметить, что с начата $30-x$ годов практически все ссылки государств на rebus mutatis (единственным исключением стало изменение Советом Лиги Наций по просьбе Швейцарии постановлений Лондонской декларации 1929 Г., относившихся к этой стране $^{38}$ ) приводили к безусловно одностороннему отказу от договора.

Существование нормы о rebus sic stantibus в opinio juris полностью подтверждается рассмотренной практикой заявлявших при- 
тязания стран, которые при отказе от договора со ссылкой на rebus mutatis были убеждены в правомерном характере своих действий, а также заинтересованных государств, молчаливо или явно выраженно признававших правомерность подобной возможности, даже если речь не шла о допущении ее к данному конкретному случаю. Поскольку к разновидности «заинтересованных» теорией международного обычая относятся не только упомянутые государства, но также и все остальные, имеющие отношение к данной области международной жизни ${ }^{39}$, то значение частных протестов скорее сводилось к исключению применения нормы о rebus sic stantibus или некоторых ее элементов в отношении систематически возражаюшего госуцарства. Так, постоянные возражения Великобритании и отчасти США были направлены прежде всего на недопустимость одностороннего отказа от договоров, что, разумеется, не могло воспрепятствовать становлению означенной нормы, а лишь исключило эту ее часть из применения к практике обеих стран, точнее, создало возможность и дальнейших ссылок на свою точку зрения, поскольку ничто не мешает им в любой момент заявить об обратном. Как известно, opinio јuris традиционно выводится из толкования фактического поведения государств. Но оно может быть выражено и путем официального заявлсния, что имело место, например, при отказе Франции от долгового соглашения с США и расторжении Египтом договора с Великобрнтанией. И что особо важно - во всех этих случаях признавалась нормативность принципа rebus sic stantibus.

Некоторые юристы, подкрепляя свое мнение об отсутствии обычной нормы о rebus sic stantibus, утверждают, что якобы «в тех редких случаях, когда договоры прекращались в результате изменения обстоятельств, доктрина использовалась исключительно ео nomine» ${ }^{40}$. Однако упоминание понятия rebus sic stantibus имело место лишь в четырех из известных нам прецедентов: при отмене капитуляций в Турции, прекращении китайско-бельгийского договора, приостановлении действия Конвенции о грузовой марке и при отказе Египта от договора с Великобританней. Но не это главное. Нельзя сделать вывод об отсутствии нормы о rebus sic stantibus ливь потому, что сторона, желавшая расторгнуть договор, не объявляла о своем понимании сути данного явления, не предлагала своей формулировки. Заявления государств, если они не содержат opinio juris, играют второстепенную роль в создании обычных норм, а основная роль отводится, как уже говорилось, фактическому поведению государств, повторяющемуся при сходных обстоятельствах. В одном лишь подобном поведении может выражаться обычноправовая норма, не будучи даже сформулированной в официальном заявлении или закрепленной каким-либо иным образом. 
Однако наиболее распространенное обоснование подхода противников нормативности клаузулы rebus sic stantibus покоится на утверждении, вполне отвечающем действительности, об отсутствии в решениях судебных органов, как внутригосударственных, так и международных, санкции на применение данного принципа в качестве обычной нормы международного права. Но, как известно, судебные решения являются лишь вспомогательным средством для определения правовых норм, а отнюдь не непременным условием их образования. В частности, национальные суды в своих действиях не могут быть независимы от первоначальных государственных притязаний, выраженных в законодательстве; их решения, выносимые во внутреннем, а не в международном плане, обязательны, к тому же (если речь не идет о странах общего права), лишь для сторон спора. Последнее правило прямо предусматривается и в отношении Международного Суда ООН статьей 59 Статута. Поэтому подобные доводы некоторых юристов не представляются убедительными, даже если не принимать во внимание их связь с пониманием самой клаузулы.

С другой стороны, столь последовательное отрицание клаузулы рядом правоведов, как правило в большинстве своем англичан или американцев, выверяющих свое мнение главным образом по ее судебному толкованию, вполне понятно: в судебных решениях и протоколах заседаний действительно содержится гораздо меньше свидетельств в пользу правомерности ссылки на rebus mutatis. Даже в известных нам двенадцати соответствующих делах, рассмотренных национальными судами, суд обычно ограничивался констатацией возможности одностороннего отказа от договора со ссылкой на rebus mutatis, не подчеркивая зависимость своих выводов от обстоятельств конкретного случая, а также не оговаривая, какой характер носит данное утверждение - нормагивный или всего лишь доктринальный ${ }^{11}$. Из трех дел, когда вопрос о влиянии изменившихся обстоятельств на силу международных договоров рассматривался Постоянной палатой международного правосудия, в двух ${ }^{42}$ она воздержалась от собственной оценки данного явления, косвенно признав, однако, в первом из них его нормативность, а в одном допустила влияние rebus mutatis лишь на толкование договорных положений ${ }^{43}$.

Из сказанного можно сделать лишь вывод о признании судами в общем возможности ссылки на rebus mutatis при одностороннем расторжении договора, и хотя эта практика, несомненно, является определенным подтверждением существования подобного права, ее все же недостаточно, согласно воззрениям представителей прежде всего англо-американской школы юридической науки, для выведения обычной нормы, с чем нельзя не согласиться. 
Но задача судебной практики в международном праве, как мы уже говорили, несколько иная. Отчасти данные судебные решения могут быть использованы для установления «наполнения» обычной нормы относительно rebus sic stantibus, однако понимание ее сути и содержания в бо́льшей мере зависит от существующей в той или иной стране правовой системы и соответствующих господствующих доктрин «наиболее квалифицированных специалистов по публичному праву» (ведь именно в трудах юристов зародилось и сформировалось учение о rebus sic stantibus, получившее различные оттенки, но в целом имеюшее и по сей день схожие черты). Поскольку практика любого из государств в части, касаюшейся международно-правовых вопросов, опирается прежде всего на мнения собственной юридической школы, то именно эти совпадения подходов создали теоретическую основу для образования обычноправовой нормы о rebus sic stantibus, ставшей, ко всему прочему, естественным компромиссом между незначительно расходящимися доктринальными толкованиями.

Таким образом, все говорит в пользу существования в международном праве - как до принятия Венской конвенции 1969 года, так, разумеется, и после - обычной нормы относительно влияния rebus mutatis на силу международных договоров. Следовательно, на вопрос о принципиальной возможности правомерной ссылки на изменившиеся обстоятельства следует дать положительный ответ, несмотря на сушествование ряда противоположных мнений.

Принимая во внимание сущность и особенности обычной нормы о rebus sic stantibus, в силу которых она подлежит изложению лишь в обшем виде, представляются нецелесообразными и противоречащими ее назначению всякие попытки извлечения из имеюшейся практики какого-либо перечня допустимых случаев, причин и объяснений применения ссылки на rebus mutatis.

С другой стороны, опираясь на совпадаюшие обстоятельства рассмотренных прецедентов и не предлагая жестких формулировок, мы вполне можем вывести основные положения этой нормы.

Во-первых, вполне достаточно, чтобы перемены, на которые ссылается государство, имели общий характер и не обязательно относились непосредственно к той области государственной жизни, ради упорядочения которой заключался договор. Так было в подавляюшем большинстве из известных нам прецедентов: договоры расторгались со ссылкой на всеобщие политические и экономические изменения (при отказе США от договора с Францией, отказе Саксонии в начале прошлого века от некоторых положений Пражского трактата $1635 \mathrm{r}^{4}$, отказе России от нейтрализации Черного моря, отмене порто-франко в Батуме, выводе французских войск из Италии, аннексии Б.оснии и Герцеговины, провозглаше- 
нии независимости Болгарии, отмене капитуляций в Турции, расторжении Норвегией своего договора с некоторыми европейскими державами; решении вопроса о китайско-бельгийском договоре, изменении положений Лондонской декларации 1920 г., прекращении британско-египетского договора и выходе Франции из военных структур НАТО) или в связи с войной и ее последствиями (в случаях прекрашения болгаро-сербского договора и приостановления действия Конвенции о грузовой марке). Необходимо также отметить, что rebus sic stantibus как общий принцип права объемлет любые случаи расторжения договоров не иначе, как по соглашению сторон, когда он не являлся недействительным ab initio и наступление оснований прекрашения не было вызвано преднамеренными действиями его участников. То есть имея в своей основе временной фактор, данное явление относится как к последующей невозможности исполнения или возникновению новой нормы права, так и к влиянию иных перемен - собственно изменений обстоятельств.

На уровне принципа различий по сути между этими основаниями прекращения обязательств не существует. Однако в международном праве на нормативном уровне они более заметны и нередко излишне абсолютизируются юристами. Обычно проводится жесткое разграничение физической, или объективной, невозможности исполнения, с одной стороны, а с другой - невозможности моральной, или субъективной, с отнесением их исключительно к случаям, соответственно, собственно невозможности исполнения и возникновению новой правовой нормы либо к правилу об изменившихся оо̆стоятельствах как к таковому. Столь однозначный подход представляется малооправданным и не нашедшим подтверждения в практике межгосударственных отношений ${ }^{45}$. K тому же после любых перемен в обстановке, в том числе если безвозвратно исчезает объект договоpa, последний, не являясь даже de facto пригодным к исполнению, de jure продолжает оставаться в силе ${ }^{46}$ и его дальнейшее сохранение находится на усмотрении участников. Если кто-либо из них сочтет необходимым официально прехратить существование договора, то возникает практическая потребность осушествить сам отказ - чисто процедурный вопрос, и если вводить по вышеупомянутым, якобы совершенно различным, основаниям прекрашения обязательств единую процедуру, направленную прежде всего на недопушение одностороннего расторжения (как сделано, к примеру, в Венской конвенции 1969 г.), то само разграничение лишается смысла. Весьма показательны в этом отношении доводы, выдвигавшиеся в ходе обсуждения в КМП проекта конвенции о праве договоров, в пользу необходимости объединения статей о невозможности исполнения и коренном изменении обстоятельств в одну ${ }^{47}$. 
Во-вторых, если, таким образом, не обязательно, чтобы перемены происходили непосредственно в области договорного регулирования и относились $\mathrm{K}$ договору напрямую, затрагивая непосредственно его объект и цели, существенным образом изменяя сферу действия обязательств и т.П., то достаточно и косвенного отношения, влияющего на договорные положения опосредованно, через понимание государством своих задач. Опять-таки подавляющее большинство известных из практики случаев это подтверждает. Основной побудительной причиной отказов служили государственные интересы, а иногда об этом прямо заявлялось, в частности при отмене порто-франко в Батуме (экономические убытки), аннексии Боснии и Герцеговины (необходимость расширить влиянне), провозглашении независимости Болгарии (препятствие свободному развитию), расторжении сербско-болгарского договора (ущемление прав), отмене капитуляций в Турции (угроза существованию государства), прекращении китайско-бельгийского договора (сдерживание свободного и естественного развития), выходе Франции из военных структур НАТО (необходимость восстановления полноты суверенитета), отказе Финляндии от некоторых статей Договора 1947 года (ущемление суверенитета). Действительно, любой государственный договор заключается с учетом государственных потребностей, однако взаимосвязь между их изменением, с одной стороны, и буквой и духом договора, с другой, не поддается подведению под какую-либо единую шкалу измерения, которая была бы действенной в отношении всех международно-правовых соглашений на всех этапах развития межгосударственных отношений. В связи с этим указанная связь бывает в большинстве случаев трудноразличимой, подчас совсем не поддаюшейся выявлению со стороны, так как лишь одному правительству или иному государственному органу, прибегаюшему $\mathrm{k}$ отказу от договора именно на основании ссылки на rebus mutatis, известно, каким образом и через какие опосредуюшие звенья перемены в наличном положении вешей, затрагивающие или изменяющие государственные приоритеты, соотносятся и вступают в противоречие с самим договором.

В-третьих, за заявлениями об отмене следовало, как правило, безусловно одностороннее прекрашение обязательств, и право государства определять судьбу договора собственным волеизъявлением не отрицалось. Известно, что мехдународный договор может быть прекращен только двумя путями ${ }^{48}$ : по согласию сторон (решению компетентного международного органа) или в силу действия права. Отказ от обязательств с использованием обычной нормы относительно rebus sic stantibus относится ко второму. Следовательно, установление обязательной примирительной процедуры, 
когда притязающее на расторжение государство не может осушествить свое право при возражении иных заннтересованных сторон и до достижения с ними наплежашего соглашения, как это предусмотрено статьей 62, склоняет к решению данного вопроса по первому пути и если не разрушает природу клаузулы, то во всяком случае делает а priori бессмысленным ее применение.

Возвращаясь к обстоятельствам Дела о юрисдикции по спорам о рыболовстве, а также к случаю отказа Финляндии от положений части III Договора 1947 года, нетрудно установить их соответствие этим трем основным сторонам обычной нормы относительно rebus sic stantibus, а следовательно, наша гипотеза относительно ее присутствня в данных прецедентах подтверждается.

В чем же тогда причина столь очевидного отличия духа и буквы двух норм: конвенционной - о коренном изменении обстоятельств и обычной - относительно rebus sic stantibus? Положения статьи 62 вряд ли могут быть только плодом стремления правоведов к справедливому идеальному мироустройству, при котором государства будут добровольно терпеть лишения во имя сохранения договора в силе. Должно существовать опредененное доктрннальное подспорье.

Кратко проследим историю становления принципа rebus sic stantibus. Правило, согласно которому временны́ е изменения действуют на договор разрушающим образом, само по себе предполагает наличие в нем двух начал — философского и собственно юридического, которые сосуществуют, к тому же, с чисто практическими целями. Такое удачное сочетание свидетельствует о том, что его глубинные истоки следует искать в эпохе, когда право имело наиболее выраженный философский характер и находилось под сильным влиянием неправовых (точнее, надправовых) идей. Причем эти идеи реально подчиняли себе соответствующие области жизни. В истории такое случалось не часто. Поскольку достоверно известно, что понятие «rebus sic stantibus» встречается у постглоссаторов, круг поиска ограничивается началом заката Римской империи и эпохой рецепции римского права, совпавшей с резким. возвышением папской власти и всепроникающим действием католнческих доктрин.

Нанболее ранние следы клаузулы обнаруживаются, во-первых, в высказываниях мыслителей ${ }^{49}$, принадлежавших к так называемому гераклито-стоическому направленню философской мысли. Его неоценимое значение состояло в создании логично завершенного учения о закономерной и нравственно оправданной возможности индивида по собственному произволению впускать поток перемен в любую статичную общность, прежде всего - в существующие правоотношения, ломая лишь некоторые встающие у него на пути 
преграды, возведенные в свое время не без его участия (в т.ч. договоры, обещания и т.П.), во имя спасения целостности всей совокупности установлений. Это учение обусловило признание римским правом естественной способности временньх изменений охазывать разрушаюшее вяияние на обязательственные правоотношения ${ }^{\text {so }}$. Во-вторых, проявления клаузулы можно найти в укрепившихся в римском праве благодаря тем же стоическим идеям и создавшимся на их основе принципам natura rerum и bona fides, принципе impossibilium nulla obligatio est, в exceptio non adimpleti contractus, в pa3личных condictiones, прежде всего в condictio causa data causa non secuta, а также в законе относительно laesio enormis - в них зародился принцип субъективно-оценочного суждения о весомости оправдывающих неисполнение обязательства препятствий, дававший право единолично определять достаточность изменений для того, чтобы начать, ссылаясь на них, прекрашение договора.

Хотя clausula rebus sic stantibus в античном мире еше не обособилась в самостоятельное правовое явление, эти два главнейших представления встали в ряд основных черт духа римского права и после рецепции последнего вместе с породившими их стоическими представлениями в целом ${ }^{51}$ стали неотьемлемой частью совокупности юридических первооснов, пронизывавших правовые системы европейских государств, но только тех, где данная рецепция имела место и оставила заметные следы.

Для образования клаузулы во времена упадка Империи не хватало третьего условия - стремления властей, имевших возможность творить право, активно воздействовать на окружаюший мир, заставляя его жить в соответствии со своими идеями, не особо стесняясь в выборе средств для достижения собственных целей. Не хватало, таким образом, того своеобразного заряда прагматизма, который позволяет правителям находить достойное идеологическое оправдание свонх действий, в обычных условиях рассматривавшихся бы не иначе, как нарушение неких нравственных законов. Такой властью в XI веке стал Папский престол, заявлявший, что «клятва, данная в ущерб интересам Церкви, недействительна» ${ }^{52}$, и освобождавший государей по этой причине от международных обязательств $^{53}$. Он распространил свою юрисдикцию практически на все области жизни и создал соответствуюшее своим потребностям право - каноническое право западнохристианской Церкви. Не случайно именно в этом праве, стремившемся при помощи соображений справедливости смягчить жесткость римского частного права, некоторые юристы видят истоки изучаемого принципа ${ }^{54}$. Во всяком случае, одно из первых более или менее связанных его изложений мы находим у Фомы Аквинского, который полагал, что нарушитель своего слова является лжецом и предателем, но может 
быть оправдан, если имело место изменение первоначальной обстановки ${ }^{55}$.

Чуть позже практичные комментаторы, также не избежавшие канонического влияния, целенаправленно возрождая, в отличие от глоссаторов, ограничившихся толкованием древних источников, дух римского права и творя из него новые нормы для применения в современной им обстановке, создали максиму omnis conventio intelligitur rebus sic stantibus, или собственно одноименную клаузулу. А.Джентили, сославшись на высказывания Балда и Алциата ${ }^{56}$, ввел ее в конце XVI - начале XVII века в доктрину международного права, где она продолжила существование под этим названием, используемая уже государствами, перенявшими от Церкви вследствне становления теории суверенитета качество единственной самодовлеющей ценности, а значит, и право собственным произволением определять пределы и продолжительность самоораничения, исходя из своих жизненных интересов.

Понятно, что клаузула rebus sic stantibus могла проникнуть в национальное право европейских государств не иначе, как в ходе окончательной рецепции римского права, вернее, того, что от него осталось после стараний глоссаторов и постглоссаторов, и укоренилась только в тех странах, где эта рецепция оказала решающее влияние на становление национальных правовых систем. Так было прежде всего в Германии, и изучаемый принцип появлется в пандектном праве ${ }^{57}$, хотя и в более пространном виде и утратив наименование. Впоследствии, с началом кодификации национального права, клаузула входит в создаваемые обшеграхданские сборники и закрепляется в целом ряде статей ${ }^{58}$, опять-таки без собственного названия, но с не менее определенным звучанием. Естественно, ввиду того, что, в отличне от права международного, в праве национапьном сушествует единая юрисдикция в отношения большинства субъектов права, их обязательная подсудность, безусловно односторонний порядок прекрашения договора, свойственный первозданной клаузуле, был заменен обычной для того или иного государства процедурой судебного разбирательства. Однако друтая ее основная часть - косвенное воздействие изменений на договор, то есть учет прежде всего неблагоприятного влияния перемен на интересы сторон, отрицательно сказываюшегося на субъективном восприятии последними его полезности, прекрасно сохранилась. Она и послужила основой для создания во Франции известной доктрины непредвиденности (doctrine de l'imprévision) и закона Файо (loi Failliot) ${ }^{59}$. Окончательно прижившись к концу XIX века в нацнональных правовых системах практически всех европейских государств н вошедшая в доктрину в качестве одного из ведуших начал обязательственного права, clausula rebus sic stantibus стала 
тем самым общим принципом права и оказала вторичное влияние на ее понимание юристами-международниками.

Действительно, вплоть до недавнего времени международное право было еще не столь удалено от национальных школ юриспруденции, и поэтому их отношение $к$ изучаемому принципу во многом передалось юристам-международникам соответствующих стран и было тем благоприятнее, чем больше в свое время право последних испытало воздействие римских и канонических доктрин. В таких государствах, Как известно, сложилась континентальная система права. Не случайно подавляюшее большинство юристов-международников стран именно континентальной правовой системы высказывается в пользу действительного существования в международном праве принципа, известного как clausula rebus sic stantibus, который обусловливает прежде всего одностороннее прекрашение договора (П. Прадье-Фодере ${ }^{60}$, А. Ривье ${ }^{61}$, А. Бонуччи ${ }^{62}$, И.А. Овчннников ${ }^{63}$, Ф. Лист ${ }^{64}$, Д. Анцилотти ${ }^{65}$, А.-В. Гефтер ${ }^{66}$, И. Блюнчли $^{67}$, Н.М. Коркунов П.Е. Казанский ${ }^{71}$, Ф.Ф. Мартенс ${ }^{72}$, А.Л. Байков ${ }^{73}$, А.М. Ладыженский ${ }^{74}$, А. Бустаманте ${ }^{75}$, Д. Харасти ${ }^{76}$, В. Богарэ ${ }^{77}$, В. Утрата ${ }^{78}$, В. Пехота ${ }^{79}$, Ф.Н. Ковалев $\left.{ }^{80}\right)$, причем признавая практически всегда достаточность косвенного отношения изменения обстоятельств $\mathbf{K}$ прекращаемым договорам и связывая это (в рамках упомянутого выше правила субъективно-оценочного сухдения) с четырьмя основными теорнями: государственных целей (Г. Еллинек ${ }^{81}$, гр. Л.А. Камаровский ${ }^{82}, \Phi . Ф$. Мартенс $\left.{ }^{83}\right)$, основных прав государства, прежде всего на сушествование и естественное развитие (гр. Л.А. Камаровский ${ }^{84}$, Н. Блюнчли ${ }^{85}$, Ф. Лаги ${ }^{86}$, В.А. Уляницкий ${ }^{87}$, И.А. Овчинников ${ }^{88}$ ), крайней необходимости (Г. Еллинек $^{89}$, А. Бонуччи ${ }^{90}$, С.А. Котляревский $\left.{ }^{91}\right)$, а также самосохранения (С.А. Котляревский ${ }^{92}$, Э. Кауфман ${ }^{93}$ ).

Сравнивая краеугольные положения обычной нормы относительно rebus sic stantibus с господствующими воззрениями на нее юристов стран континентальной системы права, обнаруживаем полное соответствне по всем основным вопросам. Иного нельзя было и ожидать, ведь эта обычная норма сложилась, как было показано, преимущественно в практике государств именно континентальной правовой системы.

Чем же тогда объясняется прохладное отношение к клаузуле rebus sic stantibus, издавна сложившееся в странах общего права, прежде всего в Англии? Причин несколько.

Во-первых, римское право оставило на английской земле куда менее значительные следы и было вытеснено местными обычаямин4.

Во-вторых, ватиканский дух гибкого взаимоприспособления догм и потребностей, потворствования необходимости, наполняв- 
ший не только саму клаузулу, но и некоторые другие доктрины канонического права, был совершенно неприемлем для установившегося в XVI веке на английской земле протестантизма*, носившего поначалу оттенок ревностного почитания незыблемости церковных принципов и враждебности ко всему, имевшему отношение к католичеству. Следствием этого явилось не только практически повсеместное исчезновение из трудов английских юристов ссылок на мнения многих бесспорных властителей умов ученого мира Запада того времени ${ }^{95}$ и римских доктрин, но даже выдержек из античных произведений. В этих условиях не могло быть и речи о принятии идеи клаузулы rebus sic stantibus английскими юристами.

B-третьих, в XVII веке судами общего права был сформулирован принцип «абсолютной» договорной ответственности, который явнлся прямым следствием понимания природы договора в английском праве как гарантии должника в отношении кредитора, причем гарантии не реального исполнения обязательства, а передачи некоторой обусловленной соглашением денежной суммы. Причем в случае неисполнения договора кредитор не имел права требовать исполнения обязательства в натуре, а лишь возврашения долга, в силу чего вопрос о невозможности исполнения, а также об оправдывающих это причинах не возникал и возникать не мог ${ }^{\text {क }}$. В 1647 году в решении по делу Paradine v. Jane было установлено, что неограниченная условием договоренность в любом случае остается в силе, если сторона, притязающая на ее упразднение, во время заключения могла требовать внесения в нее соответствующей оговорки, но не сделала этого ${ }^{97}$. От столь жесткой постановки вопроса о допустимости прекращения обязательств английские суды стали отходить лишь во второй половине прошлого века, когда сложилась доктрина тщетности договора. Под ней подразумевалась прежде всего невозможность осуществления его объекта и целей вследствие изменения обстоятельств ${ }^{98}$, которое, по меткому выражению лорда Аткина, делает его «по характеру отличным от того, каким он был при первоначальном положении вещей»9.

Примерно в то же время, а именно в 1871 году, Великобритания начинает проводить официальную политику недопущения односторонних отказов от международных договоров, чему послужила уже упоминавшаяся нами Лондонская декларация. Необходимость высказывать в связи с этим свое отношение к клаузуле rebus sic stantibus побуждает английских юристов обрашаться за примером к доктрине тщетности, которая, как справедливо подметил Дж. Брайерли, ограничена по отношению к обычной клаузуле ${ }^{100}$ и вполне

* Именно в это время клаузула переносится в международное право. 
отвечала британским внешнеполитическим устремлениям того времени. Таким бразом, английская, а в скором времени и американская (правда, в меньшей мере) доктрины международного права если и не отвергают бесповоротно клаузулу rebus sic stantibus, то наполняют прежнюю оболочку новым содержанием.

В качестве примера можно сослаться на мнения таких правоведов, ках Дж. Вайлдмен ${ }^{101}$, Р. Филлимор ${ }^{102}$, Дж. Брайерли (прямо призывавший $\mathrm{K}$ использованию доктрины тщетности для решения вопроса о допустимости прекращения международных договоров) ${ }^{103}$, Т. Лоренс ${ }^{104}$, С. Крандель ${ }^{105}$, Ч. Фаерман ${ }^{106}$, Ч. Хайд ${ }^{107}$, Г. Лаутерпахт ${ }^{108}$, Б. Джексон ${ }^{109}$, Дж. Шварценбергер ${ }^{110}$, Дж. Старк ${ }^{111}$ и др.

Понятным теперь становится практически полное отсутствие в истории Великобритании и США случаев отказа от обязательств на подобных основаниях, а также их постоянные возражения против традиционного применения ссылки на rebus mutatis другими государствами.

Таким образом, находясь как бы в стороне от международной практики расторжения договоров с использованием клаузулы rebus sic stantibus, страны общего права не оказали влияния на становление соответствующей обычно-правовой нормы.

Зато это им вполне удалось при создании конвенционной нормы о коренном изменении обстоятельств. Помимо того, что сам процесс кодификации договорного права в некотором смысле развивался по предначертанному ими пути (Гаванская конвенция 1928 г., Гарвардский проект, чьи положения были широко использованы при подготовке Венской конвенции 1969 г.), всеми четырьмя докладчиками КМП по проекту статей о праве международных договоров были представители английской школы международного права ${ }^{12}$. Итог налицо. Конвенцией сведена практически на нет возможность безусловно одностороннего отказа от договора, чему послужило и наличие значительного числа понятий, допускающих множественность толкований (в частности, нововведенное понятие «коренного» изменения), что неминуемо подводит заинтересованные государства к обсуждению в каждом конкретном случае, что под этим надлежит понимать, тем самым опять переводя односторонний отказ на путь прекрашения по соглашению сторон.

Вполне в духе классического неприятия самой возможности расторжения договора статья 62 в принципе запрещает ссылку на изменившиеся обстоятельства ${ }^{113}$, установив исключение лишь для случаев, когда перемены в обстановке затрагивают не столько интересы сторон, сколько сам договор, пронсходя в обстоятельствах, бусловивших заключение, и коренным образом изменяя сфепу действия обязательств. Тождественность по сути последнего утвер- 
ждения с изменением характера договора (по лорду Аткину) столь очевидна, что в особых доказательствах не нуждается. Само собой нашрашивается и упоминание, как того требует доктрина тшетности, последовавшей за переменами невозможности осушествления объекта и целей договора. Так оно и было. Отвергнутое в ходе обсуждения в КМП, соответствуюшее положение содержалось в первоначальном варианте статьи о теории rebus sic stantibus, предложенном Г. Вальдоком в его втором докладе ${ }^{114}$, и даже осталось в итоговом варианте статьи о прекращении договора в случае его нарушения (п. 3 b ст. 60).

Таким Фбазом, является очевидным, что применительно к созданию в рамках КМП договорной нормы о коренном изменении ббстоятельств мы имеем дело не столько с «кодификацией» существовавшего до принятия Венской конвенции 1969 года международного права, в частности обычной нормы о rebus sic stantibus, сколько с его «прогрессивным развитием» (преимушественно в русле доктрины тщетности и Лондонской декларации 1871 г.), то есть с образованием новой нормы, не совпадаюшей во всех чертах с ей предшествовавшей. Надо сказать, что именно к этому открыто призывал третий докладчик по праву договоров - Дж. Фицморис ${ }^{115}$, именно этому оказали невольное содействие некоторые члены КМП, сочтя необходимым отказаться от использования в заголовке и тексте статьи 62 названия «rebus sic stantibus» с вполне благовидной целью избежать влияния противоречивых доктринальных толкований клаузулы ${ }^{116}$, чего им, впрочем, так и не удалоь.

Итак, в настоящее время в международном праве существуют две нормы: обычная - o rebus sic stantibus и договорная - о коренном изменении обстоятельств, изложенная в статье 62 Венской конвенции 1969 года. Обе нормы имеют сходный предмет регулирования, суть которого может быть в обшем определена как отказ государства от международного договора в случаe rebus mutatis.

Обычная норма возникла еще до принятия упомянутой конвенции и после данного события существовать, разумеется, не перестала" 117 , поскольку известно, что многосторонние кодифицирующие конвенции не ведут к исчезновению обычаев, им предшествовавших, и, являясь воплощением компромиссных соглашений, не служат препятствием существованию и развитию наряду с ними аналогичных правовых предписаний на основе обычая ${ }^{118}$.

Будучи противоположно направленными, но не противореча друг другу в целом ${ }^{119}$, обе нормы имеют, несмотря на указанную разницу в содержании, практически равнозначный обтем последнего, а также свои особые случаи применения. Это изначально исключает рассмотрение их взаимодействия на основе принципа lex posterior derogat priori, тем более что по своей природе обычная 
норма о rebus sic stantibus трудно опровергаема на подобных основаниях, поскольку в ней заложены возможности постоянного развития, в том числе с учетом некоторых конвенционных основ, определенное влияние которых может проявляться в случаях ее применения на практике.

Несомненно, будучи по сути всегда более конкретной, договорная норма может влиять на обычную на основе принципа lex speciali derogat generali, что применительно к рассматриваемой совокупности вопросов может иметь место при выведении из-под действия ссылки на rebus mutatis договоров о границах, а также случаев, когда изменения в обстоятельствах произошли вследствие нарушения притязаюшей на расторжение стороной свонх обязательств по договору либо иного международного обязательства, взятого ею на себя по отношению $\mathrm{k}$ любому другому участнику договора (п. 2 ст. 62).

Обычная норма в процессе своего образования и изменения также может, в свою очередь, воздействовать на договорную норму, и если последняя вступает с ней в явное противоречие, то теряет силу. Однако в рассматриваемом случае даже признаков подобного исхода пока не наблюдалось.

Использование обычной нормы о rebus sic stantibus приобретает первостепенное значение, во-первых, в отношениях государств участников Венской конвенции 1969 года и не участвующих в ней, а также последних между собой, причем следует учесть, что таковых немало, поскольку конвенция действует на сегодняшний день лишь в отношении 77 государств (преимушественно афро-азиатских) ${ }^{120}$, ее подписали, но не ратифицировали 22 страны (в том числе США) ${ }^{121}$, а также, во-вторых, применительно ко всем договорам, заключенным государствами до вступления в силу относительно них упомянутой конвенции, как это следует из статьи 4.

$$
* * *
$$

За последние годы мы по-особенному ошутили цену непостоянства. Изменения, происшедшие в мире, вполне соответствуют обычно присутствуюшим при ссылке на rebus mutatis и в чем-то уже затронули некоторые не безразличные для России договоры. Можно ли быть уверенным, что не возникнет вопрос об их расторжении и притязающее на это государство обязательно использует статью 62, не отдав вновь предпочтение более действенной обычной норме? Вот почему особое значение приобретает взвешенность в восприятии данных норм, непредвзятое понимание их истинного соотношения. 
1 См., в частности, Kearney R., Dalton R. The Treaty on Treaties. American Journal of International Law. - 1967. - Vol. 64. - N 3. P. 542 .

2 International Court of Justice Reports. - 1973. - P. 8.

3 Ibid. - P. 39.

4 Ibid. - P. 17-21.

s Суд, к тому же, расширил возможность ссылки на перемены в наличной обстановке, причислив $\mathrm{x}$ ним обычные изменения в праве, что противоречит духу Венской конвенции 1969 года, наделяющей способностью влиять на силу договоров только вновь возникшие императивные нормы.

6 Советско-финские отношения. 1990 год. Сборник документов и материалов. - М., 1991. - С. 92. Положения части III договора 1947 года накладывали ограничения на численность и оснащенность финских вооруженных сил.

7 Там же. - С. 57-62. Последовавшее вскоре решение правительства Финляндии в точности повторяло данный проект.

8 Там же. - C. 66-73.

9 Исландия и Франция не являются ес участниками и по сей день.

10 Даниленко Г.М. Обьгай в сонременном международном праве. M., 1988. - C. $65,74,78$.

" Любопьтно отметить, что данное решение было принято по предложению Гамильтона при противодействин Джефферсона, чье отношение $\mathbf{~ в л и я н и ю ~ r e b u s ~ m u t a t i s ~ н а ~ с и л у ~ м е ж д у н а р о д н ы х ~ д о г о в о р о в , ~}$ ставшее впоследствии классическим для США, было высказано им в соответствии с запросом Вашингтона 28 апреля 1793 г. применительно к воздействию политических изменений - собьтий французской революции - на ранее заключенные Соединенньми Штатами договоры с Францией. Последние, по его мнению, должны были продолжать связывать американскую сторону, поскольку «не являются договорами между Сосдиненными Штатами и Людовиком Капетом, но между двумя государствами - Америкой и Францией; поскольку эти государства продолжают существовать, хотя в обоих за это время изменилась форма правления, эти изменения не прекращают действия указанных договоров» (цит. по Хайд Ч.Ч. Международное право, его понимание и применение Соединенными Штатами Америки. - Т. 4. - М., 1952. - С. 397). Данный подход приобретает особое звучание при решении 'опроса о якобы имевшем место в первые послереволюционные годы правомерном отхазе большевиков от ряда договоров прежних русских правительств. США, надо отметить, всегда оставляли за собой большее пространство цля маневра, нежели Великобритания. Их отношение $\mathrm{K}$ изменившимся обстоятельствам было не столь непрнмиримое, несмотря на родственность внутригосударственных правовых систем, и ссьшки на rebus mutatis встречались в истории американской дипломатии. Однако они приводили лишь к приостановлению действия договора. Основа тому была заложена делом о договоре Клэйтона-Булвера, который американцы пытались упразднить, к вящему недовольству англичан, именно на подобньх основаниях, однако конгресс не поддержал даннос предложение 
госсекретаря и согласился лишь на приостановление (Моore J. A Digest of International Law. - Vol. 3. - Wash., 1906. - P. 189-197, 210-219). Приостановление действия договора (Конвенции о грузовой марке) имело место и при единственной в нашем веке ссьлке США на доктрину rebus sic stantibus. Но даже и это мягхое решение вызвало бурю возмушения среди американских юристов (см. ниже).

12 Ках отмечает в свосй книге Дж. Фостер, «ни договорные положения, ни его преданность церхви не могли заставить Наполеона исполнить данные обещания. Ках он, тах и прочие европейские державы признали,что изменившиеся обстоятельства его от таковьг освободили» (Foster J.W. The Practice of Diplomacy. - Boston - N.Y., 1906. - P. 300).

13 По предложению, что небезьптересно, Англии в лице лорда Гранвиля (Лондонская конференция. - СПб., 1871. - С. 5).

14 Там же. - С. 9-10. Декларация относилась вопреки мнению, распространенному среди юристов стран общего права, лишь $\mathbf{k}$ данному случаюо и не создала новой нормы (Анцилотти Д. Курс международного права. - Т. 1. - М., 1961. - С. 386-387; Фердросс А. Международное право. - М., 1959. - С. 196).

15 Лондонская конференция. - СП6., 1871. - С. 7. Э. Кауфман справедливо полагал, что стороны не отрицали саму значимость клаузулы теbus sic stantibus, а лишь ее применимость в данном случае (Kaufmann E. Das Wesen des Volkerrechts und die Clausula rebus sic stantibus. Tubingen, 1911. - S. 12).

16 См. Байков АЛ. Правовое значение оговорки «rebus sic stantibus» в междувластных отношениях. - М., 1916. - С. 4-5.

17 Archives diplomatiques. $-2^{e}$ série. - T. 19. - P., 1886. - P. 324 325.

18 Archives diplomatiques. - $3^{\text {e }}$ série. - T. 109. - P., 1909. P. 275-290.

19 CM. Guggenheim P. Traité de droit international public. - T. I. Génève, 1967. - Р. 120; Ковалев Ф.Н. Коренное измснение обстоятельств: доктрина и практика. Советское государство и право. - 1970. № 3. - C. $66-67$.

20 Archives diplomatiques. $-3^{\text {e }}$ série. - T. 109. - P. 335.

21 См. Байков АЛ. Ухаз. соч. - С. 90.

${ }^{22} \mathrm{CM}$. Pouritch B. De la clause «rebus sic stantibus» en droit international public. - P., 1918. - P. 147-149.

${ }^{23}$ CM. Crandall S.B. Treaties. Their Making and Enforcement (2 ed.). Wash., 1916. - P. 442.

24 О6 этом упоминалось в статье 232 Версальского договора 1918 года (Хайд Ч.Ч. Ухаз. соч. - С. 393).

25 Притязание обосновывалось, в частности, тем, что ксобытия последних лет повлекли в политической области такие изменения, что ныне международная обстановка совершенно отлична от той, что сушествовала во время заключения дотовора» (Revue générale de droit international public. $2^{e}$ série. - P., 1924. - Р. 299-301). Под «событиями последних лет» имелись в виду прехце всего революции в России и Германии.

26 См. Фердросс А. Указ. соч. - С. 195. 
${ }^{27}$ CM. Bishop W.W. International Law. Cases and materials. - N.Y., 1953. - P. 160-162; Orfield L.B., Re E.D. Cases and Materials on International Law. - Indianapolis, 1955. - P. 62-63. Использование в данном деле ссылки на rebus sic stantibus подверглось критихе многими американскими юристами (Хайд Ч.Ч. Указ. соч. - C. 396; Briggs H.W. The Attomey General Invokes Rebus Sic Stantibus. American Journal of International Law. - 1942. - Vol. 36. - P. 89 and ff.).

28 В заявлении советского правительства говорилось, что со времени заключения договора «обстановка изменилась в корне» и «при таком положении (японо-германского союзничества) он потерял смысл и продление этого Пакта стало невозможным» (Внешняя политика Советского Союза в период Отечественной войны. T. 3. - М., 1947. - С. 166). Следует отметить, что в данном случас ссьлка на rebus mutatis имела, по-видимому, второстепенное значение, поскольку преобладающим основанием бьло нарушение Японией своих обязательств по пакту.

29 UN. Security Council. Official Records. - Second year. - N 70. P. 1747-1779; N 80. - P. 2107-2113.

30 Ковалев Ф.Н. Указ. соч. - С. 67.

31 В памятной записке советского правительства отмечалось, что вследствие подписания японо-американского договора о взаимном сотрудничестве и продлении пребывания иностранных войсх на японской территории сложилось «новое положение, при котором невозможно осуществление обещания... о передаче островов» (Правда. - 1960. -29 янв.).

${ }^{32} \mathrm{CM}$. L'Année politique, economique et diplomatique en France. 1966. - P., 1967. - Р. 226-232, 414-416. Правомерность действий Франции признавалась даже в весьма недоброжелательном по отношению к ней исследовании американских юрнстов Э. Штейна и Д. Карро, где говорилось, что ссьлки де Голля на изменившиеся обстоятельства бьли вполне оправданны (Stein E., Carreau D. Law and Peaceful Change in a Subsystem: "Withdrawal of France from the Northen Atlantic Treaty Organisation». American Journal of International Law. - 1968. Vol. 62. - P. 577-640).

33 Не только в заявлениях, а когда подтверждалось именно действием.

34 Даниленко Г.М. Указ. соч. - С. 92.

35 См. Ладыженский А.М. Отмена капитуляций в Турции. - М., 1914. - C. 1-19; Woolsey L. The Unilateral Termination of Treaties. American Journal of International Law. - 1926. - Vol. 20. - N 2. - P. 347-350; Hackworth G.H. Digest of International Law. - Vol. 5. - Ch. 16-18. - Wash., 1943. - P. 353; Hill Ch. The Doctrine of «Rebus sic stantibus» in International Law/The University of Missuri Studies. A Quarterly of Research. - Vol. 9. - July 1934. - N 3. - P. 28-29.

${ }^{36}$ CM. Guggenheim P. Op. cit. - P. 190.

37 CM. Woolsey L. China's Termination of Unequal Treaties. American Journal of International Law. - 1928. - Vol. 21. - N 2. - P. 289-295.

38 См. Guggenheim P. Op. cit. - P. 121-122.

39 Даниленко Г.М. Указ. соч. - С. 113-119.

40 Lauterpacht H. International Law. Collected Papers. - Vol. 1. - 
Cambr., 1970. - Р. 355 (цит. по Тиунов О.И. Приншип добросовестного соблюдения международньх обязательств и доктрина «геbus sic stantibus». Советский ежегодник международного права, 1978. - М., 1980. - С. 106).

41 Признание возможности ссылки на rebus mutatis при одностороннем расторжении договора имело место путем однозначного заявления в девяти делах, а именно: Люцерн против Aаpray (Taube $M$ de. L'inviolabilité des traités. Académie de droit international de la Haye. Recueil des cours. T. 32. - N 2. - Bruxeles, 1930. - P. 363); Гупер против CWA (Cases and Other Materials on International Law (2 ed.). - - St. Paul, Minnessota, 1936. - P. 933); Байер (Annual Digest of Public International Law Cases. 1919-1922. - L., 1932. - Р. 395); Лепешкин против Гозвейлер и к (Cases and Other Materials on International Law (2 ed.). - P. 123-124); Вольньий ганзейский город Бремен против Пруссии (Annual Digest of Public International Law Cases. 1925-1926. - L., 1929. - P. 353-354); Potшильд и сыповья против египетского правительства (ibid. - Р. 22); Баден, Бавария, Саксония, Вюртемберг против германского рейха (Annual Digest of Public International Law Cases. 1929-1930. - L., 1935.

P. 332-333); Бертако против Банселя и Шольтуса (Annual Digest of Public International Law Cases. 1935-1937. - L., 1941. - P. 423); Странской против Цвиностенского банка (International Law Reports. 1955. - L., 1958. - Р. 427). Это же следовало из смысла судебного решения по спору о действии в отношении Германии обязательств вошедшей в ее состав Пруссии (Annual Digest of Public International Law Cases. 1927-1928. L., 1931. - P. 85).

42 В делах: О декретах о гражданстве в Тунисе и Mapoкко (Cases and Other Materials on International Law (2 ed.). - P.198-199); O свободных зонах (Annual Digest of Public International Law Cases. 1931-1932. - L., 1938. - P. 365).

43 При вынесении решения по вопросу толкования Конвенции МОТ 1919 года о труде женшин в ночное время (ibid. - P. 413).

$44 \mathrm{CM}$. Schmidt B. Über die völkerrechtliche Clausula rebus sic stantibus sowie einige verwandte Völker rechtsnormen. - Leipzig, 1907. - S. 45 ff.; Байков А.Л. Указ. соч. - С. 2.

45 Другой храйностью является полное неприятие моральной невозможности как основания прекращения договоров и повсеместная замена ее физической, в том числе и применительно $\mathrm{K}$ принципу неизменности обстоятельств (см., например, точку зрения Дж. Фищмориса, изоженную в пункте $2 \mathrm{i}$ статьи 22 его второго доклада: Yearbook of the International Law Commission. - 1957. - Vol. 2. - P. 32).

46 По справедливому мнению Дж. Фицмориса (ibid. - P. 48-52).

47 CM. Annuaire de la Commission du droit international. - 1963. Vol. 1. - P. 152-157.

48 Как обоснованно полагал Дж. Фицморис (Yearbook of the International Law Commission. - 1957. - Vol. 2. - P. 25-28).

49 См. Палибий. Всемирная история в сорока книгах. - T. 2. - М., 1895. - С. 212-213; Цицерон Марк Туллий. Об обязанностях. Цицерон. О старости. О Дружбе. Об обязанностях. - М., 1993. - С. 65-66 и др. so Римское право не выработало, правда, на этот счет какого-либо 
единого четко сформулированного принципа. Отталкиваясь от своих общих представлений о влиянии времени на право, соотношении права и факта, по нашему мнению, заслуживающих всяческого внимания, К.А. Митюков отмечал по этому поводу: «В праве римском... влияние времени на частные права развито довольно полно; но согласно с общим ходом развития этого права оно не высказало того общего начала, что все частные права прекращаются или приобретаются вследствие истечения известного периода времени" (Митюков К.А. Курс римского права. Киев, 1912. - С. 51).

s1 О торжестве стонческого учения в европейском праве прекрасно писал Э. Ренан: «Римскому праву предстояло торжество менее шумное, нежели христианству, но в известном смысле более прочное. Вьгтесненное сначала варварством, оно воскреснет к концу средних веков, станет законом возрождающегося мира и при небольших изменениях сделается законом новейших народов. Этим-то путем великая школа стоиков, попьттавшаяся во II веке преобразовать мир и испьтавшая, как казалось, полную неудачу, в действительности одержала полную победу. Собранные классическими юристами времен Северов, искаженные и измененные Трибонианом, тексты сохранились и стали впоследствии законом всего мира» (Ренан Э. Марк Аврелий и конец античного мнра. - М., 1991. - С. 23).

s2 Dicretal. - 1. - 2. - Vol. 24. - P. 27; Sext. - 1. - 2. Vol. 2. - P. 1 .

${ }_{53}$ Taubé $M$ de. Op. cit. - P. 358.

54 Nussbaum A. A Concise History of the Law of Nation. - N.Y.. 1947. - P. 78.

ss Thomae Aquinatis. Summa Theologica. Secunda Secundae Partis. Romae, 1894. - P. 772-773.

so Gentilis A. De iure belli. - Hanoviae, 1612. - P. 244-245.

57 См. Шуршалов В.М. Основные вопросы теории международного договора. - М., 1959. - С. 193.

s8 Перечень см. Lauterpacht H. The Function of Law in the International Community. - N.Y. - L., 1973. - P. 274-276.

s9 Ibid. - P. 274-279.

60 Pradier-Fodéré P. Traité de droit international public. - 1885 . Vol. 2. - P. 933.

61 Ривье А. Учебник международного права. - М., 1893. - С. 230.

62 Бонуччи А. Оговорка rebus sic stantibus в межгосударственном праве. Журнал министерства юстиции. - 1910. - № 10. - С. $234-239$.

63 Овчинников И.А. Международное право. - СПб., 1908. - С. 233.

64 Лнст Ф. Международное право в систематическом изложении. Юрьев, 1917. - С. 24.

65 Анцилотти Д. Курс международного права. - Т. 1. - М., 1961. C. 385 .

๙ Гефтер А.-В. Европейское международнос право. - СПб., 1880. C. 193.

67 Блюнчли Н. Соврсменное международное право цивилизованных государств, изложенное в виде кодекса. - М., 1876. - С. 274.

68 Коркунов Н.М. Международное право. - СПб., 1886. - С. 117-118. 
C. 74 .

69 Камаровский Л.А. Курс международного права. - М., 1900.

70 Даневский В.П. Пособие $\mathrm{x}$ изучению истории и системы международного права. - Вып. 1. - Харьков, 1892. - С. 220.

71 Казанский П. Учебник международного права публичного и гражданского. - Одесса, 1904. - С. 266.

72 Мартенс Ф.Ф. Современное международное право цивилизованных народов. - Т. 1. - СПб., 1904. - С. 435.

73 Байков АЛ. Указ. соч. - С. 15.

74 Ладыженский А.М. Международные договоры и оговорка относительно rebus sic stantibus//Юридический вестник. 1915. Кн. 10. - № 2. - M., 1915. - C. 48.

75 Bustamante Y Sirven A.S. de. Droit international public. - T. 3. P., 1936. - P. 492.

76 Haraszti G. The Effect of a Change of Circumstances upon the Operation of International Treaties. Questions of International Law. Budapest, 1968. - P. 86-87; Haraszti G. Some Fundamental Problems of the Law of Treaties. - Budapest, 1973. - P. 372, 376.

7 Bogaret E. Le sens de la clause «rebus sic stantibus» dans le droit de gens actuel//Revue générale de droit international public. - 1966. T. 37. - N 1. - P. 50-51.

78 Outrata V. On the Principle Pacta Sunt Servanda/The Legal Principles Governing Friendly Relations and Cooperations Among States. - Leyden, 1966. - P. 138.

79 См. Тиунов О.Н. УКаз. соч. - С. 104.

sо Ковалев Ф.Н. Указ. соч. - С. 70.

"См. Камаровский Л.А. К учению о трактатах//Юридический вестник. - 1887. - T. 24. - № 5. - С. 118.

82 Камаровский Л.А. Международное право. - М., 1897. - С. 75.

${ }^{83}$ Мартенс Ф.Ф. Указ. соч. - С. 436.

84 Камаровский Л.А. Курс международного права, читаемый в 1885 / 86 гг. - Б.м., б.г. - литография. - С. 209.

85 Блюнчли Н. Указ. соч. - С. 257.

${ }^{86}$ Laghi F. Teoria dei trattati internazionali. - Parma, 1882. - P. 346365.

87 Улдницкий В.А. Международное право. - Томск, 1911. - С. 153.

88 Овчинников И.А. Указ. соч. - С. 235.

${ }^{89}$ См. Камаровский Л.А. К учению о трактатах. - С. 118.

90 Бонуччи А. УКаз. соч. - С. 240-241.

91 Котляревский С.A. K вопросу об оговорке rebus sic stantibus. Известия МИД. - 1916. - Кн. 3-4. - С. 56-57.

92 Котляревскнй С.А. Власть и право. Проблема правового государства. - М., 1915. - С. 378.

93 Kaufmann E. Op. cit. - S. 196-204.

94 Дженкс Э. Английское право. - М., 1947. - С. 25-26.

$95 \mathrm{Kak}, \mathrm{x}$ примеру, правоведов, состоявших в католических монашеских орденах, - доминиханца $\Phi$. де Витториа и иезуита Ф. Суареса. С постепенным вытеснением в международно-правовой науке 
естественно-правового направления познтивньм расхождение между юристами стран англо-американской и континентальной правовых систем на некоторьг проблемы общей теории หеждународного права стало еще заметнес.

96 Гражданское и торговое право капиталистических государств. - М., 1993. - C. 290.

97 Yearbook of the International Law Commission. - 1957. - Vol. 2. P. 60 .

98 Ibid.; Дж. Самонд и Дж. Вильммс. Основы договорного права. M., 1955. - C. 577-603.

99 В деле Bell v. Lever Bros., Ltd. (1932) (Дж. Самонд и Дж. Вильямс. Указ. соч. - C. 585).

${ }^{100}$ Brierly J.L. The Law of Nations. - Oxford, 1928. - P. 173.

101 Wildman G. Institutions of International Law. - Vol. 1. - L., 1849. - P. 175.

102 Phillimor R. Commentaries upon International Law. - Vol. 2. - L., 1885-1897. - P. 114.

${ }^{103}$ Brierly J.L. Op. cit. - P. $172-174$.

104 Laurence T. The Principles of International Law. — Boston, 1898. P. 288 .

105 Crandall S.B. Op. cit. - P. 441.

106 Fairman Ch. Implied resolutive conditions in treaties//American Journal of International Law. - 1935. - Vol. 29. - P. 219.

107 Хайд Ч.Ч. Указ. соч. - С. 393-395.

108 Lauterpacht H. International Làw. Collected Papers. - Vol. I. P. 355 .

109 Jackson B. A Manual of International Law. - L., 1947. - P. 50.

${ }^{110}$ Schwarzenberger G. A Manual of International Law. - L., 1947. P. 67.

111 Stark J.G. An introduction to international law. - L., 1954 . P. $324-327$.

112 Причем одни из самых преданных - Дж. Брайерли, Г. Лаутерпахт, Дж. Фицморис и Г. Вальдок.

113 Эту мысль выразил и О.И. Тиунов, отнеся ее, правда, к доктрине rebus sic stantibus, поскольку нормативность последней он не признавал: "... Направленность этой статьи (62-й) противоположна содержанию доктрины «rebus sic stantibus»" (Тиунов О.И. Указ. соч. - С. 106).

114 Annuaire de la Commission du droit international. - 1963. Vol. 2. - P. 83.

115 Yearbook of the International Law Commission. - 1956. - Vol. 1. P. 227.

116 Annuaire de la Commission du droit international. - 1963. Vol. 1. - P. 148-152.

117 В некоторьх работах по данному вопросу это, $\mathrm{K}$ сожалению, иногда обходится стороной (см., например, Ерпьлева Н.Ю. Доктрина неизменных обстоятельств в международном праве. Диссертация на соискание ученой степени кандидата юридических наук. - М., 1991. - С. 131).

${ }^{118}$ Даниленко Г.М. Указ. соч. - С. 43, 55, 147. 
119 Иначе применение обычной нормы было бы невозможньм, поскольку, как полагал Г.М. Даниленко, «наличие таких (сходных договорных) положений исключает возможность ссылюк на обычное право вопреки (выделено мною. - M.K.) положениям конвенции» (Даниленко Г.М. Указ. соч. - С. 55).

${ }^{120}$ Европейских - 29, из них вообще не участвуют в-конвснции, например, Франция, Норвсгия, Португалия, Ирландия, Албания, Румыния.

121 Сведения на конец апреля 1995 года.

Статьа поступила в редакцию в мас 1995 г. 